\title{
Introspecting the Causes of Absenteeism of Pre-Service Teachers
}

\author{
Richard M. Bañez ${ }^{1}$, Rubilyn M. Latido ${ }^{1}$, Nora V. Marasigan ${ }^{1} \&$ Conrado D.M. Reyes ${ }^{1}$ \\ ${ }^{1}$ College of Teacher Education, Batangas State University JPLPC-Malvar, Batangas, Philippines \\ Correspondence: Richard M. Bañez, College of Teacher Education, Batangas State University JPLPC-Malvar, \\ Batangas Province, 4232, Philippines. E-mail: unsunghero25@yahoo.com
}

Received: September 14, 2018; Accepted: October 1, 2018; Published: November 14, 2018

\begin{abstract}
Educators have recognized the importance of school attendance to learners' academic growth and development. School attendance is often linked to positive school performance and considered as predictor of academic success. This notion makes it imperative to examine the potential causes of absenteeism to prevent students to be at risk of habitual truancy. Hence, this survey type of research determined the causes of absenteeism of teacher education students along attitude, school, and home-related factors. Twenty-three teacher education students who were purposively chosen as respondents based on their attendance record perceived attitude-related and home-related factors as highly contributory to their absenteeism. They had considered their current program not as their field of interest nor their first choice in selecting academic programs, and were also easily affected by their parents' quarrel. Moreover, they considered school-related factors as contributory to absenteeism as the classrooms' ventilation appeared not conducive to learning for the respondents. An intervention program strengthening the monitoring of students' attendance is highly recommended in this study.
\end{abstract}

Keywords: low absenteeism, habitual truancy, pre-service teachers

\section{Introduction}

Regular class attendance has been long recognized important to students' academic growth. Students' presence in classroom provided numerous opportunities for task engagements and meaningful interactions that can support the enhancement of their thinking and social skills. It is in this contention that a number of educators include attendance as part of course requirements and often remind students on this academic policy during class orientations. Handbooks on students' norms and conduct also specify consequences of habitual absenteeism and given strict implementation as part of the guidance services of educational institutions.

In tertiary education, students are expected to be conscious of their attendance in their numerous courses as it is found to be predictor of success in completing a degree. Mendoza (2016) stated that attendance significantly influenced college students' academic performance. Students who are conscious of their attendance benefit academically as they keep abreast on the lectures, learning tasks and occasional requirements in each of the courses they enrolled. Often times, students communicate conflict in schedule and priority that can lead to their absences and make arrangement with their professors to mend with the tasks or topics that the learners have missed. Despite this, alarming cases of students' habitual truancy have been encountered by educators. Yeide and Kobrin (2009) considered this unexcused chronic absences as a potential risk for students to fail and dropout from school. This often leads to undesirable results like academic incompetency, substance addiction, and criminal activity.

Spradlin et al. (2012) also affirmed that students who habitually make absences are likely to dropout. Unmanageable cases of school dropout seem to result to serious problems. Malcolm et al. (2003) identified academic underachievement, poor social skills, and loss of confidence as effects of chronic absenteeism which often resulted to loss of career opportunities. This alarming situation is equated with poverty, increasing numbers of out-of-school youths, and deviant behaviors that are detrimental to society.

Commitment to school attendance is important and beneficial for students as it often relates to positive school performance and achievements. Hence, teachers are given responsibility to monitor students' attendance to avoid habitual truancy. Habitual truancy is often described as frequent absences from classes committed by students without due reasons (Yeide \& Kobrin, 2009). These frequent absences predict alarming cases of academic failure, school dropout, substance addiction, and involvement in criminal activity among adolescents.

The school has the commitment to engage students to meaningful and active classroom participation to avoid absenteeism; hence, it becomes imperative to determine reasons of students' truancy from school. Once causes 
and reasons had been identified, possible solutions or interventions can be devised and implemented to encourage students to be conscious of their attendance to their classes which can increase their opportunity for learning engagement. This increased in opportunity for learning tasks can motivate students to perform academically.

The researchers as core faculty members of the College of Teacher Education at Batangas State University JPLPCMalvar, Batangas, Philippines identified the causes resulting to chronic absenteeism of teacher education students with the end view of proposing intervention program to minimize absenteeism among teacher education students.

\subsection{Objectives of the Study}

This study determined the causes of absenteeism among teacher education students at Batangas State University JPLPC-Malvar, Batangas, Philippines. Specifically, this work endeavored to determine the causes of absenteeism of the respondents in terms of attitude, school, and home-related factors that can serve as basis in proposing an intervention program to minimize teacher education students' absenteeism.

\section{Method}

This research utilized the descriptive-survey design to determine the causes of absenteeism among 23 teacher education freshmen who were officially enrolled at Batangas State University JPLPC-Malvar, Batangas, Philippines during the First Semester of Academic Year 2015-2016. These students were purposively chosen based on the reported cases of habitual absenteeism by course instructors and professors as reflected in the record of the guidance office in the campus. With the help of the guidance counselor, consent was solicited among students with reported cases of habitual truancy to participate as respondents of the study. Through the provision of consent form, students who agreed to participate were oriented on the nature of the study, and the confidentiality of the data to be gathered from their responses on the administered researcher-made questionnaire. The anonymity of the identity of the respondents was established by excluding profile variable and treating the gathered responses as grouped data.

The questionnaire was used to draw out data on three identified factors that commonly served as reasons why students are frequently not attending their classes. It covers 15 item statements wherein five items illustrate the possible causes of habitual absenteeism in each identified factor namely: attitude, school, and home-related factors. The questionnaire underwent content and face validations by experts who are composed of a registered psychometrician, a registered guidance counselor, and a licensed professional teacher who secured the congruence of the item statements on the constructs measured in the study and other considerations such as clarity of the item statements, balance, and the like. The pertinent data gathered from the respondents' responses on the researchermade questionnaire served as the basis to propose intervention program which can minimize absenteeism of teacher education students. Moreover, the following mean ranges with their corresponding interpretations were used to analyze the computed mean: 3.51-4.00: Strongly Agree/Highly Contributive; 2.51-3.50: Agree/Contributive; 1.51-2.50: Slightly Agree/Slightly Contributive; 1.00-1.50: Disagree/Not Contributive.

\section{Results}

\subsection{Teacher Education Students' Absenteeism in Terms of Attitude-Related Factors}

Attitude which is commonly comprised of beliefs, feelings, and behavioral intentions can influence students' engagement in learning tasks which is likely to motivate them to attend classes in school. This favorable influence of positive attitude in students' schooling can help them attain success in their respective academic program and courses. Hence, it is important to examine the influence of attitude-related factors on the school attendance of teacher education students.

Table 1. Respondents' Absenteeism in Terms of Attitude-related Factors

\begin{tabular}{lll}
\hline Statements & Mean & Interpretation \\
\hline $\begin{array}{l}\text { 1. I am not interested in my studies for the current program that I } \\
\text { am enrolled is not my first choice. }\end{array}$ & 3.83 & Strongly Agree \\
$\begin{array}{l}\text { 2. I feel lazy because I find the classroom activities in learning our } \\
\text { lessons boring. }\end{array}$ & 3.17 & Agree \\
$\begin{array}{l}\text { 3. I do not want to wake up early for I am tired of mingling with the } \\
\text { same faces in school. }\end{array}$ & 3.43 & Agree \\
4. I cannot concentrate in my studies for I have other priorities. & 3.74 & Strongly Agree \\
5. I do not want to make any assignment for I find it uninteresting. & 3.52 & Strongly Agree \\
\hline Overall & $\mathbf{3 . 5 4}$ & Highly Contributory \\
\hline
\end{tabular}


Table 1 illustrates that attitude-related factors were highly contributory to teacher education students' absenteeism (overall mean $=3.54$ ). This result can be traced to their preference on teacher education programs which were not their first choice (mean $=3.83$ ). This negative preference on pre-service teachers' training seems to make them uninterested in making assignments on concepts relative to teaching $($ mean $=3.52)$ and drive them to accomplish other priorities than studying (mean 3.74). These undesirable condition toward studying and unfavorable attitude on the teaching profession often isolate them from other students taking the same courses as they are tired of mingling with them (mean $=3.43$ ). This self-imposed isolation appears to indicate the irrelevance of their current academic programs to their personal aspirations which can decrease their motivation for studying and attending their classes. Bañez (2016) affirmed this notion by stressing that students' motivation for schooling depends on the relevance of the concepts they study to their lives and aspirations.

\subsection{Teacher Education Students' Absenteeism in Terms of School-Related Factors}

The school where favorable classroom atmosphere is set by the way teacher and students manage the learning environment and class interactions. These school-related factors are important in encouraging students to attend their classes and refrain from absences.

Table 2. Respondents' Absenteeism in Terms of School-related Factors

\begin{tabular}{lll}
\hline Statements & Mean & Interpretation \\
\hline 1. I cannot understand my instructor's lessons because I failed to cope & 3.13 & Agree \\
up with the previous topics. & 3.13 & Agree \\
2. I do not like my instructors for they are inconsiderate. & 3.70 & Strongly Agree \\
3. Our classrooms are not conducive to learning for they are not well- \\
ventilated. & 3.26 & Agree \\
4. It is noisy inside the classroom. & 3.13 & Agree \\
5. My classmates bully me. & $\mathbf{3 . 2 7}$ & Contributory \\
\hline Overall &
\end{tabular}

Table 2 describes the respondents' absenteeism in terms of school-related factors. It was found out that the classroom atmosphere was not conducive for learning due to poor ventilation (mean $=3.70)$. This poor classroom ventilation can result to discomfort among students driving them to be noisy (mean $=3.26$ ) and to engaged in irritating activities such as bullying (mean $=3.13$ ). This alarming condition can result to students' failure of recalling and associating the previously discussed topics to the new lessons discussed by their teachers (mean $=$ 3.13) which can cause students to detest their instructors (3.13). In general, the school-related factors were found to be contributory to teacher education students' absenteeism (overall mean $=3.27$ ) as the poor ventilation of the classrooms has caused students' discomforts which engaged them to irritating activities unsafe for the entire class.

According to Henry (2007), the feeling of discomfort resulted from poor learning environment can lessen the feeling of security and safety among students that can force them to skip school. Similarly, Balfanz and Byrnes (2012) noted that students' avoidance of harassment and bullying caused by poorly managed classroom initiated them to commit absences as they find the school unsafe.

\subsection{Teacher Education Students' Absenteeism in Terms of Home-Related Factors}

The manner that students are raised at their home may influence their schooling; thus, it is equally important to examine students' absenteeism in terms of school-related factors.

Table 3. Respondents' Absenteeism in Terms of Home-related Factors

\begin{tabular}{lll}
\hline Statements & Mean & Interpretation \\
\hline 1. My parents always quarrel and I easily get affected with it. & 3.70 & Strongly Agree \\
2. My parents do not care about my studies. & 3.48 & Agree \\
3. I do many household chores. & 3.35 & Agree \\
4. I have no money to buy snacks and to finance school projects. & 3.61 & Strongly Agree \\
5. My parents ask me to be absent from class to do other tasks. & 3.65 & Strongly Agree \\
\hline Composite Mean & $\mathbf{3 . 5 6}$ & Highly Contributory \\
\hline
\end{tabular}


Table 3 shows that home-related factors were highly contributory to teacher education students' absenteeism (overall mean $=3.56$ ). This unfavorable situation to students' class attendance appeared to be the result of their parents' habitual quarrel (mean $=3.70$ ) that was likely to be influenced by the financial crisis experienced by their families. This financial crisis experienced by students was detrimental to their schooling as they had no means to finance their school projects (mean $=3.61)$ and often requested by their parents to be absent from their classes to perform other tasks (mean $=3.65)$. This event can discourage students from schooling which can lead to a feeling that nobody cares about their studying (mean $=3.48$ ) resulting to their habitual truancy. This is affirmed by Balfanz and Byrnes (2012) by stressing that poverty can discourage students from attending their classes to fulfill other family obligations.

\subsection{Intervention Program to Minimize Absenteeism of Teacher Education Students}

After determining the causes of absenteeism of teacher education students, the researchers proposed interventions which aimed to minimize their absenteeism. The suggested interventions are presented in tabular form along with each specific purpose and brief description.

Table 4. Intervention Program to Minimize Absenteeism of Teacher Education Students

\begin{tabular}{lll}
\hline Activity & Objectives & Brief Description \\
\hline $\begin{array}{l}\text { Establish effective } \\
\text { monitoring practices }\end{array}$ & $\begin{array}{l}\text { Monitor students' attendance } \\
\text { religiously to identify students } \\
\text { who are at risk of habitual } \\
\text { truancy }\end{array}$ & $\begin{array}{l}\text { Collaboration among course instructors, professors, } \\
\text { and guidance counselor can be strengthen to identify } \\
\text { students who are prone to chronic absenteeism and } \\
\text { implement appropriate intervention programs }\end{array}$ \\
\hline $\begin{array}{l}\text { Introduce a mentoring } \\
\text { system to encourage } \\
\text { students to see the } \\
\text { importance of teaching } \\
\text { profession }\end{array}$ & $\begin{array}{l}\text { Improve school attendance } \\
\text { and motivation to complete } \\
\text { the teacher education } \\
\text { programs }\end{array}$ & $\begin{array}{l}\text { Alumni with inspiring and successful stories in the } \\
\text { teaching profession may be introduced to teacher } \\
\text { education students to emphasize the significant roles } \\
\text { that teachers play in the society; thus, promoting } \\
\text { positive attitude toward the profession }\end{array}$ \\
\hline $\begin{array}{l}\text { Individualize } \\
\text { intervention practices }\end{array}$ & $\begin{array}{l}\text { Augment preventive measures } \\
\text { through } \\
\text { mechanisms intervention }\end{array}$ & $\begin{array}{l}\text { Connect students with the support they need to } \\
\text { attend school regularly }\end{array}$ \\
\hline
\end{tabular}

\section{Discussion}

Chronic absenteeism among students engaged in teacher training can be avoided if the relevance of their current academic programs to their personal aspirations has been clarified. As secondary to students' preference in academic programs, the benefits and prestige of teaching as profession can be clarified among students to develop their positive attitude towards pre-service teachers' training which can increase their motivation in studying and engaging in learning tasks relevant to teachers' training that can strengthen their commitment to school attendance. This often leads to the identification of their capabilities that are responsive to the demand of the teaching profession. This notion is affirmed by the Self-Efficacy Theory that emphasizes the importance of people's judgement on their capabilities to the achievement of their goals and aspirations (Hoy and Miskel, 2008). However, students who refused to see themselves as future teachers can be given opportunity to discover their aptitude and be provided with option to pursue the academic program they deem beneficial to their future career. This discovery of students' own potentials can stimulate genuine love for studying that can enhance their school attendance.

Poverty which is rampant in third-world countries is found detrimental to students' school attendance. This financial problem encountered by students can be addressed by the administrations of different educational institutions through strengthening their financial aid and assistance to deserving students. This financial aid and assistance can be provided in the form of scholarship grants or compensation for clerical work for students as support to various offices that are short in manpower. This clerical job can orient students on the world of work while gaining a way to finance their schooling which can lessen their absences due to financial problem.

The findings of this study call for the development and validation of strategic plan that can help students who are at risk of habitual truancy to increase their motivation on studying and attending their classes.

\section{References}

Balfanz, R., \& Byrnes, V. (2012). Chronic absenteeism: Summarizing what we know from nationally. Available Data. Baltimore Johns Hopkins University Center for Social Organization of Schools. 
Bañez, R. M. (2016). Recency or relevance: A quest for pedagogical framework in teaching Philippine and World literature in senior high school. Asia Pacific Journal of Multidisciplinary Research, 4(4), 78-86.

Henry, K. L. (2007). Who's skipping school: Characteristics of truants in 8th and 10th grade. The Journal of School Health, 77(1), 29-35. https://doi.org/10.1111/j.1746-1561.2007.00159.x

Hoy, W. K., \& Miskel, C. G. (2008). Educational administration theory, research, and practice. New York: Mc Graw Hill.

Malcolm, H., Davidson, J., Wilson, V., \& Kirk, S. (2003). Absence from school: A study of its causes and effects in seven LEAs. Nottingham: National Foundation for Educational Research.

McCluskey, C. P., Bynum, T. S., \& Patchin, J. W. (2004). Reducing chronic absenteeism: An assessment of an early truancy initiative. Crime and Delinquency, 50(2), 214-234. https://doi.org/10.1177/0011128703258942

Mendoza, R. O. (2016). Attendance and parental support: Its influence to college students' academic performance. Asia Pacific Journal of Multidisciplinary Research, 4(4), 121-129.

Spradlin, T., Stephanie, D., Chen, M., Shi, D., Chen, M., Han, J., \& Ciernak, K. (2012). Examining the prevalence, scale, and impact of chronic absence in Indiana: Student-level analysis. Bloomington, IN: Center for Evaluation \& Education Policy.

Yeide, \& Kobrin (2009). Truancy literature review. Office of Juvenile Justice and Delinquency Prevention. Retrieved from http://www2.dsgonline.com/dso/Truancy\%20Literature\%20Review.pdf

\section{Copyrights}

Copyright for this article is retained by the author(s), with first publication rights granted to the journal.

This is an open-access article distributed under the terms and conditions of the Creative Commons Attribution license (http://creativecommons.org/licenses/by/4.0/). 